\section{Compost Teas and Reused Nutrient Solution Suppress Plant Pathogens In Vitro}

\author{
Xiuling Tian and Youbin Zheng ${ }^{1}$ \\ School of Environmental Science, University of Guelph, 50 Stone Road W., \\ Guelph, Ontario, N1G 2W1, Canada; and Vineland Research and Innovation \\ Centre, Vineland, Ontario, Canada
}

Additional index words. diatomaceous earth, manure, mycorrhizae, pine bark, vermicasting

\begin{abstract}
In vitro testing was conducted to evaluate the inhibition potential of three compost teas (pine bark, manure, and vermicasting), Root Rescue Landscape Powder ${ }^{\circledR}$ (a mix of mycorrhizae and other beneficial microbes), waste diatomaceous earth (DE; from beer brewing), and a greenhouse nutrient solution, which had been reused for 20 years on six plant pathogens: Fusarium foetens, Rhizoctonia solani, Sclerotinia sclerotiorum, Phytophthora cryptogea, Pythium intermedium, and $P$. ultimum. The test materials showed in vitro inhibition on most of the test pathogens. Pine bark tea suppressed growth of all six pathogens, and inhibition exceeded $50 \%$ after 10 days of coincubation. Vermicasting tea showed over $40 \%$ inhibition against $S$. sclerotiorum and $F$. foetens; manure tea showed $42 \%$ inhibition against $F$. foetens; DE showed $40 \%$ inhibition against $F$. foetens, $S$. sclerotiorum, and $R$. solani; whereas reused greenhouse nutrient solution showed $56.7 \%$ inhibition against $R$. solani and $43.4 \%$ inhibition against $F$. foetens; Root Rescue showed $66 \%$ inhibition against $P$. intermedium. The results suggest that the six test materials have potential in the control of these soil- and water-borne pathogens in plant production system.
\end{abstract}

An increasing number of greenhouses are reusing nutrient solutions in their operations to protect the environment and save water and fertilizer (Richard et al., 2006). One major concern of this practice is the risk of dispersal of soil- and water-borne plant pathogens within the recirculation system (Richard et al., 2006). Various water disinfection technologies have been used in controlled environment plant production systems including greenhouse and nursery operations. However, these technologies are usually ineffective in controlling pathogens in potting substrates, especially when the substrates contain organic materials. For example, the frequently used oxidants (e.g., ozone, chlorine, and chlorine dioxides) may react with organic potting substrates before they reach residual levels that are lethal to plant pathogens. Similarly, control of plant pathogens with copper ion is also challenging because organic potting substrates can bind copper ions, preventing them from reaching critical levels for pathogen control (Zheng et al., 2004).

An alternative to nutrient solution disinfestation technologies in controlled environment

Received for publication 19 Dec. 2012. Accepted for publication $11 \mathrm{Feb} .2013$.

We thank Ontario Centres of Excellence, Agriculture and Agri-Food Canada's Growing Forward Program, and Canadian Ornamental Horticulture Alliance for providing the financial support and Coralie Sopher for her inputs during the preparation of this manuscript.

${ }^{1}$ To whom reprint requests should be addressed; e-mail yzheng@uoguelph.ca. plant production systems to reduce pathogen pressure in reused nutrient solution is the use of pathogen-suppressing growing substrates and the addition of beneficial microorganisms.

Compost teas (water extracts from the fermentation of compost materials) have been reported to act as natural pesticides and may contain various biopesticidal microbes and organic chelators (Scheuerell and Mahaffee, 2002). Using composted organic materials such as municipal wastes, hardwood bark, and vermicompost as soil amendments have been shown to reduce root rot diseases (Dissanayake and Hoy, 1999; Hoitink et al., 1991; Szczech, 1999; Trillas-Gay et al., 1986).

More than 10 yeast genera were used to control soilborne plant diseases (El-Tarabily and Sivasithamparam, 2006). Yeasts are required for beer brewing and are often removed, in conjunction with other unwanted solids, at the end of the brewing process by filtration through powdered DE. We are not aware of any work designed to investigate the potential of using liquid from DE slurry to control plant pathogens.

During a survey of the status of greenhouse nutrient solution recirculation in Ontario, Canada (Richard et al., 2006), it was found that some greenhouses had been reusing their nutrient solutions for more than 20 years without increased disease incidence. Microbiological analysis of some of these nutrient solutions did not detect any plant pathogens (data not shown).

The objective of this study was to evaluate the inhibitory potential of three compost teas (pine bark, manure, and vermicasting), Root Rescue Landscape Powder ${ }^{\circledR}$ (a mix of mycorrhizae and other beneficial microbes), waste DE from beer brewing, and a greenhouse nutrient solution that had been reused for more than 20 years on six water- or soilborne plant pathogens commonly found in Ontario greenhouses.

\section{Materials and Methods}

Inhibition subtracts used in trials. Three commercially available compost products, Root Rescue Landscape Powder ${ }^{\circledR}$ (Root rescue), waste $\mathrm{DE}$, and a reused greenhouse nutrient solution (RNS) were used to test their inhibition potential on six soilborne plant pathogens. The three composts used were vermicasting (Forterra Environmental Corp., Puslinch, Ontario, Canada); manure compost (unknown quantities of cattle, sheep, and horse manures, onion and carrot scraps, and egg shells; Dingo Farms, Bradford, Ontario, Canada); and composted pine bark (passed through 6.4-mm mesh; GroBark, Milton, Ontario, Canada). The Root Rescue Landscape Powder ${ }^{\circledR}$ (Redbud Supply Inc., Ancaster, Ontario, Canada) contains nine species of endomycorrhizal fungi, 10 species of ectomycorrhizal fungi, Trichoderma harzianum, T. konigii, and 14 species of bacteria. The DE was collected as a waste material from a local beer brewery (Sleeman Brewery Ltd., Guelph, Ontario, Canada). The liquid portion of the waste was used for tests. The reused nutrient solution was collected from a holding tank in a commercial greenhouse in southwest Ontario, Canada, that had been recycling the solution for more than 20 years and no major plant pathogen outbreak had been reported during this period. In this greenhouse, potted ornamental plants were grown (e.g., Campanula, Aphelandra, Gerbera, and others) on subirrigation benches. Compost tea was prepared using a Compost Tea System (Compost Tea System $25^{\mathrm{TM}}$, Eugene, OR). Briefly, the compost tea system was filled with deionized water, the compost basket immersed into the water tank, and a bubble stone placed into the tank to start the brew cycle. The tanks were continually aerated and the compost tea thoroughly mixed before dispensing. The brew cycle was $24 \mathrm{~h}$.

Plant pathogens. The plant pathogenic microbes tested were commonly found in greenhouse crops: F. foetens, R. solani, S. sclerotiorum, $P$. intermedium, P. ultimum, and Phytophthora cryptogea. Before inoculation, $F$. foetens, $R$. solani, and S. sclerotiorum isolates were grown on potato dextrose agar (PDA) in petri plates with a diameter of $90 \mathrm{~cm}$; Pythium intermedium, P. ultimum, and Phytophthora cryptogea were subcultured onto V8 medium and incubated at room temperature until the mycelium fully covered the entire agar surface.

Evaluation of microbial population in solutions. The population densities of bacteria, filamentous fungi, yeasts, and actinomycetes were evaluated in all tested samples. The samples were serially diluted in water with five dilutions: $1: 10,1: 10^{2}, 1: 10^{3}, 1: 10^{4}$, and $1: 10^{5}$. A $100-\mu \mathrm{L}$ solution of each sample was spread onto three media in petri plates as follows: one-tenth trypticase soy agar, colloidal 
chitin agar, and PDA amended with $100 \mathrm{mg}$ streptomycin and $50 \mathrm{mg}$ of chloramphenicol per liter. Total colony-forming units $/ \mathrm{mL}$ solution were counted after a $48-$ to $72-\mathrm{h}$ incubation period at room temperature. The tests were conducted with five replicates per dilution. The fungi isolates were examined using microscopy and presumptive identification made based on morphological and cultural characteristics.

Evaluation of microbial activity in compost. The total microbial activity in composts was determined by measuring the rate of hydrolysis of fluorescein diacetate [3', 6'- diacetylfluorescein (FDA)] following methods of Adam and Duncan (2001). The fluorescein concentration in compost filtrates was measured at an absorbance of $490 \mathrm{~nm}$ using a spectrophotometer. The fluorescein adsorbing value at each concentration indicated the fluorescein adsorbing percentage and an average total value is given for composts. The results were converted to absorbance/g dry weight. The microbial activity was expressed as micrograms of hydrolyzed FDA per gram dry weight of pine bark, vermicasting, and manure compost per minute.

Inhibition test. The test materials were evaluated for inhibition effect against the six microbial isolates. One 5-mm diameter mycelial disc of a pathogen from an actively growing culture was placed at one side of the petri plates $(90 \mathrm{~mm}$ diameter) containing PDA. An autoclaved polyvinyl chloride ring (1.2 cm diameter, $0.9 \mathrm{~cm}$ height) was seated firmly in the agar at the opposite side of the plate at an equal distance from the periphery of the plate as the mycelial disc. The teas, DE liquid, or RNS each with a volume of $400 \mu \mathrm{L}$ was then poured into the autoclaved ring. Root Rescue Powder was dissolved in water according to the manufacturer's recommendation to make a solution with a final concentration of $0.6 \mathrm{~g} \cdot \mathrm{L}^{-1}$. The plates were sealed with parafilm and incubated at room temperature $\left(\approx 23{ }^{\circ} \mathrm{C}\right)$ for up to $10 \mathrm{~d}$. The ability of the test materials to inhibit the pathogen growth was assessed after incubation by measuring the radius of the mycelia from the edge of colonies in the direction toward the solution ring. The results were converted into percentage inhibition of radial growth in relation to the radial growth of the pathogen in the control plate (Jinantana and Sariah, 1998). The test was repeated once, each with five replicates.

Statistical analysis. Statistical analysis was conducted using SAS Version 9.1 (SAS Institute Inc., Cary, NC) to establish significance of the effects of all factors $(P \leq 0.05)$. Means were separated by the least significant difference test $(P \leq 0.05)$.

\section{Results and Discussion}

The inhibition test revealed that most compost teas inhibited radial mycelial growth of the six pathogens after $10 \mathrm{~d}$ of incubation, but their efficiencies varied (Fig. 1). The pine bark tea significantly suppressed mycelial growth of all test pathogens in vitro with an inhibition over $50 \%$ after $10 \mathrm{~d}$. Vermicasting tea showed

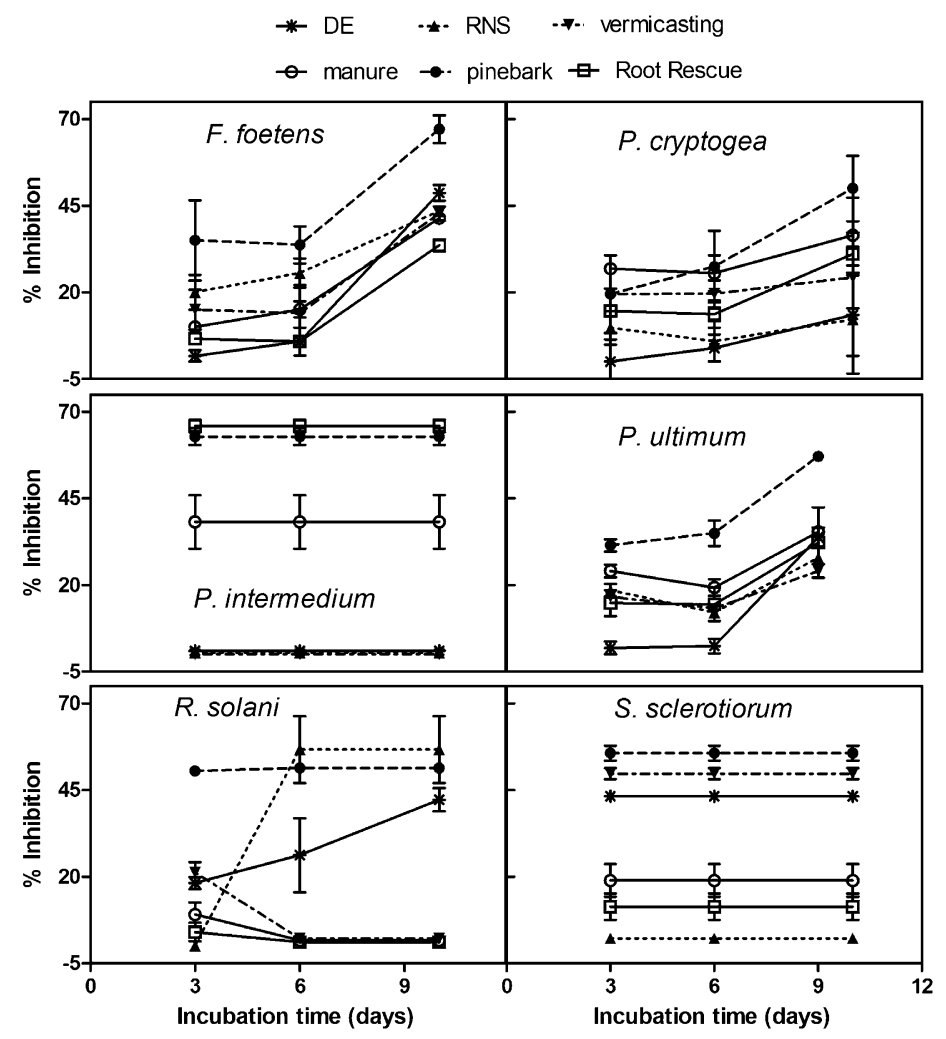

Fig. 1. Inhibition rate of six pathogens grown in vitro after varying incubation times by three compost teas (pine bark, manure, and vermicasting), Root Rescue, waste diatomaceous earth (DE), and reused greenhouse nutrient solution (RNS). Data are means $\pm \operatorname{SE}(n=10)$.

biocidal activity against $S$. sclerotiorum $(50 \%)$ and $F$. foetens $(43 \%)$ after $10 \mathrm{~d}$ incubation, whereas initially effective for the first $6 \mathrm{~d}$ but effectiveness did not last the entire 9 days on $R$. solani; and there was no inhibition on Pythium intermedium at all. Manure tea showed good inhibition on $F$. foetens $(42 \%)$, P. intermedium (38\%), Phytophthora cryptogea (37\%), and Pythium ultimum (35\%), but was not effective for $S$. sclerotiorum and $R$. solani. DE showed effective inhibition to test pathogens except Phytophthora cryptogea and $P$. intermedium over the $9 \mathrm{~d}$ incubation. RNS inhibited $R$. solani, $F$. foetens, and Pythium ultimum after $10 \mathrm{~d}$ incubation but did not show inhibition on $P$. intermedium, P. cryptogea, and S. sclerotiorum. Root rescue inhibited tested pathogens (31\%) after $10 \mathrm{~d}$ incubation but had no effect on $R$. solani and S. sclerotiorum.

The results of the dilution tests (Table 1) showed that the compost teas contained large and varied microbial populations with bacteria and filamentous fungi as the predominant microorganisms. These bacteria, fungi, and yeast might display antagonism. Similarly, these groups of microorganisms have been observed in compost teas produced from horse manure, cattle manure, and grape in Germany, and these antagonists were highly effective in reducing the development of the potato late blight pathogen Phytophthora infestans (Ketterer, 1990). In the present study, Trichoderma spp. were among the main filamentous fungi isolated from the compost teas. T. harzianum, a filamentous fungus that is commonly found in the rhizosphere, was accepted as one of the most potent biocontrol agent against plant diseases and was used as an antagonist against many soilborne pathogens in the past few years (Margolles-Clark et al., 1996). T. harzianum was shown to act as a mycoparasite against a range of economically important aerial and soilborne plant pathogens both in the field and in greenhouses (Chet, 1987). In the present study, actinomycetes were only isolated from composted manure. The biocontrol mechanisms that contribute to suppression of soilborne plant pathogens include parasitism, production of antimicrobial compounds (antibiosis), competition for nutrients and colonization sites, and induction of plant systemic resistance (Fravel, 1988; Han et al., 2000). Suppression of fusarium seedling blight of oats by pine bark mulch and compost was associated with the presence of beneficial microbes in addition to chemical inhibitors or physical factors (Boyd-Wilson and Walter, 2002). In this test, although pine bark tea showed lower microbial populations, it has the greatest efficacy. Krause et al. (1997) report that composted pine bark fortified with Flavobacteriaum balustinum and T. hamatum has been very effective in controlling fusarium wilt of cyclamen, rhizoctonia disease as well as Phytophthora and Pythium root rots of other greenhouse container crops.

Sufficient microbial activity levels to hydrolyze FDA were observed in the pine bark, vermicasting, and manure composts (Table 2 ). 
Table 1. Microbial populations of three compost teas, reused nutrient solution (RNS), waste diatomaceous earth from beer brewing (DE), and Root Rescue Landscape Powder ${ }^{\circledR}$ (Root Rescue).

\begin{tabular}{lcccc}
\hline & \multicolumn{3}{c}{ cfu/mL } \\
\cline { 2 - 5 } & Bacteria & Filamentous fungi & Actinomycetes & Yeast \\
\hline Vermicasting tea & $3.2 \times 10^{7}$ & $1.0 \times 10^{6}$ & 0 & $3.2 \times 10^{7}$ \\
Manure tea & $3.7 \times 10^{7}$ & $3.3 \times 10^{4}$ & $1.3 \times 10^{6}$ & $2.5 \times 10^{7}$ \\
Pine bark tea & $3.5 \times 10^{5}$ & $4.7 \times 10^{4}$ & 0 & $1.6 \times 10^{5}$ \\
RNS & $1.9 \times 10^{5}$ & $1.0 \times 10^{4}$ & 0 & 0 \\
DE & 0 & 0 & 0 & 0.0 \\
Root Rescue $^{\mathrm{z}}$ & $4.0 \times 10^{3}$ & $9.6 \times 10^{2}$ & 0 & 0 \\
\hline
\end{tabular}

cfu $=$ colony-forming units.

${ }^{z}$ Root rescue was dissolved in water according to the manufacturer's recommendation to make a solution with a final concentration of $0.6 \mathrm{~g} \cdot \mathrm{L}^{-1}$.

Table 2. Percentage fluorescein absorption by substrates and fluorescein concentration in compost extracts.

\begin{tabular}{|c|c|c|c|}
\hline Compost & $\begin{array}{c}\text { Percentage fluorescein absorbed } \\
\text { by substrate at } 490 \mathrm{~nm}\end{array}$ & $\begin{array}{l}\text { Fluorescein concn in compost } \\
\text { extracts }\left(\mu \mathrm{g} \cdot \mathrm{mL}^{-1}\right)^{\mathrm{z}}\end{array}$ & FDA $\left(\mu g \cdot g^{-1}\right)^{z}$ \\
\hline Vermicasting & 1.119 & $5.01 \pm 0.03$ & $4.91 \pm 0.03$ \\
\hline Manure & 0.929 & $4.12 \pm 0.09$ & $3.22 \pm 0.09$ \\
\hline Pine bark & 1.472 & $6.66 \pm 0.02$ & $5.55 \pm 0.02$ \\
\hline
\end{tabular}

${ }^{\mathrm{z}}$ Data are means of three replicates \pm SE.

Boehm and Hoitink (1992) found that populations of Pythium ultimum and pythium root rot were suppressed as long as the rate of hydrolysis of FDA was sustained above $3.2 \mu \mathrm{g} \cdot \mathrm{min}^{-1} \cdot \mathrm{g}^{-1}$ dry weight potting mix. The present study found that all the fluorescein adsorbing value for three composts was below $1.5 \%$, which was in agreement with Schnürer and Rosswall (1982) who stated that the fluorescein adsorption by soil was mostly lower than $5 \%$.

DE suppressed the growth of $S$. sclerotiorum $(43.3 \%), R$. solani $(42.2 \%)$, and $F$. foetens $(48.7 \%)$ to a greater extent than the growth of the oomycete isolates (Fig. 1). Because yeasts were the only microbes isolated from DE (Table 1), suppression of fungal pathogens by $\mathrm{DE}$ might be the result of the presence of viable yeasts. El-Mehalawy (2004) showed that the rhizosphere yeasts Saccharomyces unispora and Candida steatolytica significantly reduced the incidence of wilt disease of beans caused by $F$. oxysporum through the production of antifungal diffusible metabolites. El-Tarabily (2004) also stated that three rhizosphere yeasts from sugar beet significantly reduced root rots of mature sugar beet caused by $R$. solani under greenhouse conditions.

RNS inhibition on different pathogens was different (Fig. 1): $56.7 \%$ for $R$. solani, $43.4 \%$ for $F$. foetens, but almost no suppression for S. sclerotiorum $(2.2 \%)$ and $P$. intermedium $(0.5 \%)$. The RNS contained a diverse microbial population composed of bacteria, filamentous fungi, and yeasts (Table 1). This may explain why no increased soil- or water-borne disease incidences were observed in southern Ontario greenhouses that have adopted nutrient recirculation technologies (Richard et al., 2006). These results indicate that increasing beneficial microbial diversity can suppress pathogens in controlled-environment plant production systems.

Root Rescue showed strong inhibition on $P$. intermedium $(66.0 \%)$, moderate inhibition (30\%) on P. ultimum, Phytophthora cryptogea, and $F$. foetens, but little inhibition on S. sclerotiorum (11.4\%) and R. solani $(1.1 \%)$
(Fig. 1). Lower populations of bacteria and filamentous fungi were observed, but actinomycetes or yeasts were not isolated from this product (Table 1). Kaye et al. (1984) stated that the disease severity of Pythium ultimum was greater in non-mycorrhizal treatments than mycorrhizal treatments. Gerdemann (1975) suggested possible mechanisms of direct disease tolerance by mycorrhizal-treated plants such as production of antibiotics or other inhibitory compounds, influencing root exudates, or changes in the microbial rhizosphere populations.

In summary, the test materials demonstrated various levels of suppression on most of the test pathogens in vitro, suggesting that these materials have potential for use in plant production systems (e.g., greenhouse and nursery operations) for water- and soil-borne pathogen control. Greenhouse trials are needed to confirm their efficacy in different growing substrates and also to determine optimum application rates.

\section{Literature Cited}

Adam, G. and H. Duncan. 2001. Development of a sensitive and rapid method for the measurement of total microbial activity using fluorescein diacetate (FDA) in a range of soils. Soil Biol. Biochem. 33:943-951.

Boehm, M.J. and H.A.J. Hoitink. 1992. Sustenance of microbial activity in potting mixes and its impact on severity of Pythium root rot of poinsettia. Phytopathology 82:259-264.

Boyd-Wilson, K.S.H. and M. Walter. 2002. Suppression of fusarium seedling blight by composted and uncomposted radiata pine bark. Australas. Plant Pathol. 31:57-61.

Chet, I. 1987. Trichoderma-application, mode of action and potential as a biocontrol agent of soilborne plant pathogenic fungi, p. 137160. In: Chet, I. (ed.). Innovative approaches to plant disease control. Wiley, New York, NY.

Dissanayake, N. and J.W. Hoy. 1999. Organic material soil amendment effects on root rot and sugarcane growth and characterization of the materials. Plant Dis. 83:1039-1046.
El-Mehalawy, A.A. 2004. The rhizosphere yeast fungi as biocontrol agents for wilt disease of kidney bean caused by Fusarium oxysporum. Intl. J. Agr. Biol. 6:310-316.

El-Tarabily, K.A. 2004. Suppression of Rhizoctonia solani diseases of sugar beet by antagonistic and plant growth-promoting yeasts. J. Appl. Microbiol. 96:69-75.

El-Tarabily, K.A. and K. Sivasithamparam. 2006. Potential of yeasts as biocontrol agents of soilborne fungal plant pathogens and as plant growth promoters. Mycoscience 47:25-35.

Fravel, D.R. 1988. Role of antibiosis in the biocontrol of plant diseases. Annu. Rev. Phytopathol. 26:75-91.

Gerdemann, J.W. 1975. Vesicular-arbuscular mycorrhizae, p. 575-591. In: Torrey, J.G. and D.T. Clarkson (eds.). The development and function of roots. Academic Press, London, UK.

Han, D.Y., D.L. Coplin, W.D. Bauer, and H.A.J. Hoitink. 2000. A rapid bioassay for screening rhizosphere microorganisms for their ability to induce systemic resistance. Phytopathology 90:327-332.

Hoitink, H.A.J., Y. Inbar, and M.J. Boehm. 1991. Status of compost-amended potting mixes naturally suppressive to soil borne diseases of floricultural crops. Plant Dis. 75:869-873.

Jinantana, J. and M. Sariah. 1998. Potential for biological control of Sclerotium foot rot of chilli by Trichoderma spp. Pertanika, J. Trop. Agr. Sci. 21:1-10.

Kaye, J.W., F.L. Pfleger, and E.L. Stewart. 1984. Interaction of Glomus fasciculatum and Pythium ultimum on greenhouse-grown poinsettia. Can. J. Bot. 62:1575-1579.

Ketterer, N. 1990. Studies on the effect of compost extracts on the leaf infestation of potato and tomato by Phytophthora infestans and on infection of grapevine by Plasmopara viticola, Pseudopeziza tracheiphila and Uncinula necator. Doctoral Dissertation. University of Bonn, Germany.

Krause, M.S., C.A. Musselman, and H.A.J. Hoitink. 1997. Impact of sphagnum peat decomposition level on biological control of rhizoctonia dampingoff of radish induced by Flavobacterium balustinum 299 and Trichoderma hamatum 328. Phytopathology 87:S55.

Margolles-Clark, E., C.K. Hayes, G.E. Harman, and M. Penttila. 1996. Improved production of Trichoderma harzianum endochitinase by expression in Trichoderma reesei. Appl. Environ. Microbiol. 62:2145-2151.

Richard, S., Y. Zheng, and M. Dixon. 2006. To recycle or not to recycle? Greenhouse Canada December:20-25.

Scheuerell, S. and W. Mahaffee. 2002. Compost tea: Principles and prospects for plant disease control. Compost Sci. Util. 10:313-338.

Schnürer, J. and T. Rosswall. 1982. Fluorescein diacetate hydrolysis as a measure of total microbial activity in soil and litter. Appl. Environ. Microbiol. 43:1256-1261.

Szczech, M.M. 1999. Suppressiveness of vermicompost against fusarium wilt of tomato. J. Phytopathol. 147:155-161.

Trillas-Gay, M.I., H.A.J. Hoitink, and L.V. Madden. 1986. Nature of suppression of fusarium wilt of radish in a container medium amended with composted hardwood bark. Plant Dis. 70:10231027.

Zheng, Y., L. Wang, and M. Dixon. 2004. Response to copper toxicity for three ornamental crops in solution culture. HortScience 39: $1116-1120$ 